\title{
Мініінвазивні технології в хірургічному лікуванні абсцесів печінки
}

\begin{abstract}
Мета роботи: провести аналіз ефективності традиційних і мініінвазивних методів хірургічного лікування абсцесів печінки, що дасть змогу удосконалити підходи до кожного з відомих способів лікування із розробкою алгоритму дій хірурга у різних клінічних випадках.

Матеріали і методи. У статті викладено досвід лікування 142 хворих із абсцесами печінки. 89 операційних втручань було виконано лапаротомним доступом, 36 черезшкірних дренувань - за допомогою УЗД навігації, 17 втручань - за допомогою мініінвазивного лапароскопічного дренування. Вік пацієнтів коливався від 26 до 84 років. У жінок діагностували АП в 1,41 раза частіше, ніж у чоловіків. Тривалість від початкової маніфестації до госпіталізації становив від 4 діб до 1 місяця. Супутню патологію виявлено в 121 пацієнта (85,2 \%).

Результати досліджень та їх обговорення. Абсцеси печінки найчастіше розвивалися в таких сегментах печінки: III сегмент -

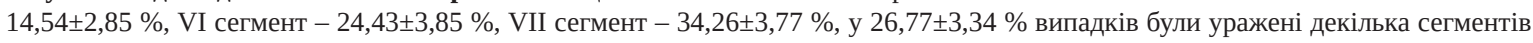
печінки. Ускладнення проявлялися нагноєнням післяопераційної рани - 6 (6,37 \pm 3,25 \%), ексудативний плеврит праворуч - 7 $(5,16 \pm 2,85 \%)$, жовчотеча - 4 (3,01 \pm 2,58 \%), пневмонія - 6 (6,04 \pm 2,63 \%), рання злукова кишкова непрохідність - 3 (3,03 \pm 2,14 \%). Тривалість перебування в стаціонарі пацієнтів із мініінвазивними методами лікування абсцесів печінки була менша $(5,7 \pm 0,4$ днів) порівняно з відкритими операціями $(14,7 \pm 1(\mathrm{p}<0,05))$. Перевагу варто віддавати мініінвазивним способам лікування, які мають високу ефективність, безпечність, скорочують терміни перебування пацієнтів у стаціонарі та знижують летальність до 7,04 \%. При неефективності обраного методу хірургічна тактика повинна мати ескалаційний принцип, який полягає у своєчасному переході до більш дієвого та інвазивного методу.
\end{abstract}

Ключові слова: абсцес печінки; черезшкірні ехоконтрольовані мініінвазивні втручання; відкриті операції.

Постановка проблеми і аналіз останніх досліджень та публікацій. Абсцес печінки (АП) вперше описав Гіппократ і до сьогодні є грізним захворюванням, частота якого повільно зростає (10 випадків на 100000 населення). Найчастіше джерелами даного захворювання, враховуючи анатомічні та фізіологічні особливості печінки, є: біліарний тракт - 60,6 \%, через портальну вену чи системно - 23,8 \%, криптогенна - $18,5 \%$, гематогенна - 14,7 \%, пряме розповсюдження від гнійної патології верхнього травного тракту 4,0 \%, травматична - 2,9 \%, вторинне інфікування кісти чи пухлини - 2,9 \%, післяопераційне - $1 \%$. Права частка вражається частіше, ніж ліва, співвідношення становить 2:1, ураження двох часток одночасно спостерігають у 5 \% випадків [1]. Найчастіше збудниками АП є асоціації бактерій 3 Escherichia coli та Klebsiella pneumoniae [2]. Xiрургічне лікування абсцесу печінки вперше було описано у класичному огляді Охснера ще у 1938 р. і полягало у дренуванні абсцесу [3].

Розробка і впровадження в клінічну практику нових радіологічних методів $[4,5]$, методів мікробіологічної ідентифікації збудників та розвитку дренажних технік не тільки відкрили нові можливості для діагностики [2], але і змінили традиційні підходи до лікування АП шляхом ширшого засто- сування мініінвазивних методів лікування - черезшкірної пункції та дренування порожнини гнійника [3, 4, 6, 7]. До впровадження мініінвазивного дренування прогноз для пацієнтів з АП був вкрай несприятливим, летальність сягала до 60-80 \% [3, $8,9]$. На даний час, незважаючи на впровадження сучасних методик лікування абсцесів печінки, летальність є високою 5-30 \% [ 10]. При 15 і більше балів шкали АРАCHE II на момент госпіталізації летальність пацієнтів, старших 65 років, при АП суттєво підвищується. Без лікування це захворювання призводить до летальності [11, 12].

Мета роботи: провести аналіз ефективності традиційних і мініінвазивних методів хірургічного лікування АП, що дасть змогу удосконалити підходи до кожного відомого способу лікування із розробкою алгоритму дій хірурга в різних клінічних випадках.

Матеріали і методи. Всього ми провели 163 оперативні втручання при бактеріальних АП у 142 хворих на базі Клінічного високоспеціалзованого хірургічного центру з мініінвазивними технологіями ВОКЛ імені М. І. Пирогова з 2008 до 2020 p.

Підрахунок проводили після кінцевого ефективного хірургічного втручання: 89 операцій було 
виконано лапаротомним доступом, 36 черезшкірних дренувань - за допомогою УЗД навігації, 17 втручань - за допомогою мініінвазивного лапароскопічного дренування. Летальність - 10 випадків внаслідок пізнього звертання пацієнтів, за рахунок розвитку міліарних абсцесів, печінкової недостатності та синдрому поліорганної недостатності, що склало 7,04 \%. Післяопераційної летальності не спостерігали.

Вік пацієнтів коливався від 26 до 84 років, із медіаною в 58 років. У жінок АП діагностували в 1,41 раза частіше, ніж у чоловіків. Тривалість від початкової маніфестації до госпіталізації становив від 4 діб до 1 місяця. Супутню патологію виявлено у 121 пацієнта (85,2 \%).

Всі операції проводили під загальним внутрішньовенним та ендотрахеальним знеболенням. Санацію порожнини абсцесу та очеревинної порожнини виконували із застосуванням 0,02 \% розчину “Декаметоксину”.

Пункційне дренування АП проводили через незмінну паренхіму печінки з товщиною не менше 2 см $з$ метою запобігання підтіканню гною в очеревинну порожнину. Ми використовували дренажні трубки за типом “pig - tail” розміром 13-14 Fr. Після ретельного доопераційного сонографічного позиціювання абсцесу із нанесенням міток виконували розріз шкіри до 1 см. Пункцію правої частки виконували по середній аксілярній лінії справа, лівої частки - в епігастрії. Після початку евакуації гною трубку фіксували вузловим швом до шкіри, а зовнішній кінець з’єднували із стерильним контейнером.

Хірургічне лапароскопічне чи відкрите лікування АП проводили шляхом мобілізації печінки від зв'язок, спорожнення гнійника й обробки його порожнини: видалення некротичних тканин i секвестрів із порожнини АП. Перевагу віддавали дренуванню порожнини абсцесу не менше ніж двома трубчастими дренажами. В окремих випадках (при кровотечі) доводилося використовувати гемостатичні губки. У випадках крайового або пристінкового розташуванні АП без капсули ми використовували оригінальний метод операції - економну резекцію типу “фенестрації”. Дана методика полягає у тому, що після розтину i спорожнення абсцесу, ревізії його порожнини проводять висічення його зовнішньої стінки, яка являє собою тонку (до 5 мм) ділянку печінкової паренхіми, розташованої над порожниною абсцесу. Потім виконували ретельну механічну очистку тампонами частини стінки абсцесу, яка залишилась, з підведенням до неї латексно-трубчатого дренажу. Сегментарну або часткову резекцію печінки виконували при повній деструкції печінкової паренхіми, множинних і міліарних абсцесах, розташованих в одній частці печінки, ерозії великих печінкових судин. Абсцес видаляли в межах здорових тканин паренхіми печінки. У хворих зі щільно осумкованими АП, практично повністю заміщених фіброзними тканинами, виконували резекцію печінки в межах одного або декількох сегментів. Обов'язково проводили гістологічне дослідження фрагменту стінки гнійника для виключення туберкульозного, пухлинного та іншого походження АП.

Хірургічні методи, які ми застосовували при лікуванні бактеріальних АП, представлено в таблиці 1.

Всім пацієнтам призначали стартову антибіотикотерапію: поєднання третього покоління цефалоспорину із аміноглікозидом або метронідазолом, що охоплювало типову мікрофлору (грамнегативні палички та грампозитивні коки).

Проведення попереднього аналізу ефективності традиційних і мініінвазивних методів хірургічного лікування АП дає змогу виробити оптимальні підходи до лікування АП.

Таблиця 1. Види операційного доступу до абсцесу печінки

\begin{tabular}{|c|c|c|}
\hline \multirow{2}{*}{ Доступ } & \multicolumn{2}{|c|}{ Кількість операцій } \\
\hline & абс. & $\%$ \\
\hline $\begin{array}{l}\text { Черезочеревинний (підреберний, параректальні доступи, } \\
\text { лапаротомія верхньо-серединна) спосіб розкриття АП }\end{array}$ & 89 & 62,7 \\
\hline $\begin{array}{l}\text { Черезшкірне дренування за допомогою } \\
\text { УЗД-навігації }\end{array}$ & 36 & 25,3 \\
\hline Лапароскопічне дренування & 17 & 12 \\
\hline Всього & 142 & 100 \\
\hline
\end{tabular}


Результати досліджень та ї обговорення. Загальний стан пацієнтів був вкрай тяжкий у 10 пацієнтів (7 \%), тяжкий - у 84 пацієнтів (59,1\%), помірного ступеня тяжкості у 40 пацієнтів (28,2 \%) та наближався до задовільного у 9 пацієнтів (5,6 \%).

Щодо локалізації, то АП найчастіше розташовувалися у таких сегментах печінки: III сегмент $14,54 \pm 2,85 \%$, VI сегмент $-24,43 \pm 3,85 \%$, VII сегмент $-34,26 \pm 3,77 \%$, у 26,77 $\pm 3,34 \%$ випадків були уражені декілька сегментів печінки.

При виконанні бактеріальних посівів зі стінки абсцесу на мікрофлору найчастіше виявляли грамнегативні (E. coli, Klebsiella spp., Citrobacter spp., P. aeruginosa та Proteus spp.) і грампозитивні (Enterococus spp., Staphylococcus spp., Streptococcus spp.) аеробні бактерії, а також гриби роду Candida.

Ускладнення були представлені нагноєнням післяопераційної рани - 6 (6,37 $\pm 3,25 \%)$, ексудативний плеврит праворуч - 7 (5,16 $\pm 2,85 \%)$, жовчотеча - 4 (3,01 $\pm 2,58 \%)$, пневмонія - 6 (6,04 \pm 2,63 \%), рання злукова кишкова непрохідність - 3 (3,03 $\pm 2,14 \%)$. Тривалість перебування в стаціонарі пацієнтів після застосування мініінвазивних методів лікування АП була менша $(5,7 \pm 0,4$ днів) порівняно із відкритими операціями $(14,7 \pm$ $1(\mathrm{p}<0,05))$.

Аналіз результатів лікування пацієнтів дав можливість сформувати таку тактику хірургічного лікування хворих:

1. Оптимальним вибором першого методу лікування у більшості гострих АП є пункційно-аспіраційна санація під контролем УСГ (при відсутності вираженої запальної інфільтрації, секвестрів і багатокамерності). Неефективність 2-3 сеансів санації слід вважати показанням до подальшого хірургічного дренування.

2. У випадках гострих АП сформована капсула завтовшки більше 5 мм, вибором методу лікування $є$ пункційно-дренажна санація під контролем УЗД, КТ або ангіографа.

3. Для пристінкових АП без капсули оптимальним методом лікування є фенестрація. При їх локалізації в передніх сегментах печінки доцільно використовувати лапароскопічний доступ.

4. Наявність секвестрів вимагає їх ретельного видалення будь-яким зручним способом (лапароскопічна або лапаротомна фенестрація i секвестректомія або різні види резекції печінки).

5. При багатокамерних гнійниках великих розмірів (> 10 см) слід застосовувати резекцію печінки в межах здорових тканин.

6. При хронічних, паразитарних і пухлинних абсцесах (завжди $є$ щільна капсула) основним методом лікування $є$ резекційні операції (перицистектомія, клиноподібна резекція або гемігепатектомія).

7. Методика санації абсцесу значною мірою визначається його локалізацією: санацію у вентральних III-VII сегментах печінки виконують під контролем УЗД або лапароскопічно, в дорзальних сегментах (I, частково II і VIII) - лапаротомним доступом. Водночас санацією 3 лапаротомного доступу і дренуванням порожнини гнійника може закінчиться будь-яка операція з приводу одиничного АП.

Для адекватної оцінки пацієнта 3 перерахованими положеннями від фахівця променевої діагностики необхідно отримати інформацію про: локалізацію АП за сегментами, розмір і форму, наявність капсули (з її характеристикою), наявності секвестрів, перетинок, глибини розташування відносно поверхні печінки. Наявність ультразвукових ознак щільної капсули і склерозу (фіброзу) прилеглої паренхіми є ознакою тривалого існування в подальшому залишкової інфікованої порожнини. Окрім цього, на вибір способу лікування істотне значення має тяжкість загального стану пацієнта, яку оцінюють спільно з анестезіологом. Мініінвазивні технології виконують здебільшого під місцевою анестезією або на тлі поверхневого загального наркозу. У разі застосування резекційних методик або санації лапаротомним доступом необхідне загальне знеболення з ШВЛ.

При загрозі для життя внаслідок такої операції (операційний ризик IV-V ст. за Гологорським) слід зменшити об'єм хірургічного втручання і вимушено виконати менш травматичне мініінвазивне втручання.

Висновки. Всі хірургічні методи лікування АП, які ми застосовували, можна розділити на три групи: аспіраційні, дренажні і резекційні. Спосіб санації визначали індивідуально, враховуючи морфологічні особливості гнійника - його розмір, наявність секвестрів, перегородок, щільність капсули, перипроцесу. Тип хірургічного доступу визначали локалізацією гнійника, тяжкістю стану пацієнта, оснащенням клініки і наявністю клінічного досвіду хірурга. Позитивний ефект лікування значною мірою залежить від правильного вибору стартового методу лікування. Перевагу слід віддавати мініінвазивним способам лікування, які мають високу ефективність, безпечність та скорочують терміни перебування пацієнтів у стаціонарі. При неефективності обраного методу хірургічна тактика повинна передбачати ескалаційний принцип, який полягає у своєчасному переході до більш дієвого та інвазив- 
ного методу за такою послідовністю: пункційно-аспіраційна санація під контролем УЗД, дренування під контролем УЗД, лапароскопічне дренування, лапароскопічна економна резекція типу “фенестра-

\section{СПИСОК ЛІТЕРАТУРИ}

1. URL: https://emedicine.medscape.com/article/188802-overview\#a5;

2. Virulent clones of Klebsiella pneumoniae: identification and evolutionary scenario based on genomic and phenotypic characterization / S. Brisse, C. Fevre, V. Passet [et al.] // PLoS One. 2009. - Vol. 4 (3). - P. e4982

3. Pyogenic abscess of the liver II. An analysis of forty-seven cases with review of the literature / A. Ochsner, M. DeBakey, S. Murray // Am. J. Surg. - 1938. - Vol. XL. - P. 292-319.

4. Ультразвукова діагностика абсцесу печінки, можливості і здобутки / М. Ю. Ничитайло, Г. Ю. Машковський, М. В. Костилев, Е. Ю. Лебедева // Клінічна хірургія. - 2012. - № 10. - С. 12-15.

5. Досвід застосування інтервенційної сонографії в лікуванні пацієнтів із бактеріальними абсцесами печінки / М. В. Безручко, С. І. Панасенко, О. С. Осипов [та ін.] // Клінічна хірургія. - 2020. - Т. 87, № 3-4. - С. 31-34.

6. Characteristics and management of pyogenic liver abscess: A European experience / C. Serraino, C. Elia, C. Bracco [et al.] // Medicine (Baltimore). - 2018. -Vol. 97 (19). - P. e0628. doi:10.1097/MD.0000000000010628

7. Liver abscesses: A 10- year Vinnytsia university study. EU- ція”, лапароскопічна періцистектомія, лапаротомна економна резекція типу “фенестрація”, лапаротомна періцистектомія, лапаротомна резекція печінки, лапаротомне дренування.
REKA / V. Shaprynskyi, V. Makarov, V. Suleimanova [et al.] // Health Sciences. - 2020. - No. 1. - P. 10-14. - Access mode : https://doi.org/10.21303/2504-5679.2020.001122

8. Pyogenic liver abscess: An audit of 10 years' experience / T. C. Y. Pang, T. Fung, J. Samra [et al.] // World J. Gastroenterol. - 2011. - Vol. 17, No. 12. - P. 1622 - 1630.

9. Машковский Т. Ю. Порівняльна оцінка ефективності відкритих та мініінвазивних втручань в лікуванні абсцесу печінки та скупчень рідини післяопераційного походження / Т. Ю. Машковский // Клінічна хірургія. - 2012. - № 12. - С. 5-8. 10. Сучасні тенденції лікування бактерійних абсцесів печінки / Т. Є. Баб'як, В. Г. Жемела, Т. М. Іванків, М. П. Павловський // Міжнародна науково-практична конференція "Малоінвазивна хірургія без кордонів”: матер. конф. // Шпитальна хірургія. - 2001. - № 2. - С. 13-15.

11. Церетели И. Ю. Анализ факторов риска летальности при абсцессах печени / И. Ю. Церетели, Г. Г. Ахаладзе, Э. И. Гальперин // Анналы хирургии и гепатологии. - 2004. - Т. 9, № 1. - C. $69-78$.

12. Pyogenic liver abscess in the elderly: clinical features, outcomes and prognostic factors / S. C. Chen, Y. T. Lee, C. H. Yen [et al.] // Age Ageing. - 2009. - No. 38 (3). - P. 271-276.

\section{REFERENCES}

1. https://emedicine.medscape.com/article/188802-overview\#a5;

2. Brisse, S., Fevre, C., Passet, V., Issenhuth-Jeanjean, S., Tournebize, R., Diancourt, L. \& Grimont, P. (2009). Virulent clones of Klebsiella pneumoniae: Identification and evolutionary scenario based on genomic and phenotypic characterization. PLoS ONE, 4 (3), p.e4982.

3. Ochsner, A., DeBakey, M. \& Murray, S. (1938). Pyogenic abscess of the liver. The American Journal of Surgery, 40 (1), 292-319. 4. Nychytailo, M., Mashkovskyi, H., Kostylev, M., \& Lebedeva, E. (2012). Ultrazvukova diahnostyka abstsesu pechinky, mozhlyvosti i zdobutky [Ultrasound diagnosis of liver abscess, opportunities and achievements]. Klinichna khirurhiia - Clinical Surgery, 10, 12-15 [in Ukrainian].

5. Bezruchko, M., Panasenko, S., Osipov, O., Drabovskyi, V. \& Rybalka, Y., (2020). Dosvid zastosuvannia interventsiinoi sonohrafii v likuvanni patsiientiv iz bakterialnymy abstsesamy pechinky [Experience of application of interventional sonography in treatment of patients with bacterial hepatic abscesses]. Klinichna Khirurhiia - Clinical Surgery, 87 (3-4), 31-34 [in Ukrainian]. 6. Serraino, C., Elia, C., Bracco, C., Rinaldi, G., Pomero, F., \& Silvestri, A. et al. (2018). Characteristics and management of pyogenic liver abscess. Medicine, 97 (19), e0628. DOI: 10.1097/ md.0000000000010628;

7. Shaprynskyi, V., Makarov, V., Suleimanova, V., Shaprynskyi, Y., \& Skalskyi, S. (2020). Liver abscesses: a 10-year Vinnytsia university study]. Eureka: Health Sciences, 1, 10-14.

DOI: 10.21303/2504-5679.2020.001122 [in Ukrainian].

8. Pang, T. (2011). Pyogenic liver abscess: An audit of 10 years' experience. World Journal of Gastroenterology, 17(12), 1622. DOI: 10.3748/wjg.v17.i12.1622;

9. Mashkovskyi, T. (2012). Comparative estimation of open and miniinvasive interventions in the treatment of hepatic abscesses and accumulations of liquid of postoperative genesis [Porivnialna otsinka efektyvnosti vidkrytykh ta miniinvazyvnykh vtruchan $\mathrm{v}$ likuvanni abstsesu pechinky ta skupchen ridyny pisliaoperatsiinoho pokhodzhennia]. Klinichna khirurhiia - Clinical Surgery, 12, 5-8 [in Ukrainian];

10. Babiak, T., Zhemela, V., Ivankiv, T., \& Pavlovskyi, M. (2001). Current trends in the treatment of bacterial liver abscesses [Suchasni tendentsii likuvannia bakteriinykh abstsesiv pechinky]. Shpytalna khirurhiia - Hospital Surgery, 2, 13-15 [in Ukrainian];

11. Cereteli, I., Ahaladze, G., \& Galperin, J. (2004). Analiz faktorov riska letalnosti pri abstsessakh pecheni [Analysis of risk factors mortality in liver abscess ]. Annaly hirurgii i gepatologii Annals of Surgery and Hepatology, 9 (1), 69-78. Retrieved from: http://hepatoassociation.ru/ASH/Volumes/Pdf91/ZherAha91.pdf [in Russian];

12. Chen, S., Lee, Y., Yen, C., Lai, K., Jeng, L., \& Lin, D. et al. (2008). Pyogenic liver abscess in the elderly: clinical features, outcomes and prognostic factors. Age and Ageing, 38 (3), 271276. DOI: 10.1093/ageing/afp002.

Отримано 22.07.2021 
V. O. SHAPRINSKYI, A. M. FORMANCHUK, Y. V. SHAPRINSKYI, V. M. MAKAROV, O. A. KAMINSKIY, T. V. FORMANCHUK, O. I. CHERNICHENKO

National Pirogov Memorial Medical University, Vinnytsya

\section{MINIMALLY INVASIVE TECHNOLOGIES IN THE SURGICAL TREATMENT OF LIVER ABSCESSES}

The aim of the work: to analyze the effectiveness of traditional and minimally invasive methods of surgical treatment of liver abscesses (LA), which will improve the approaches to each of the known methods of treatment with the development of an algorithm for the surgeon in different clinical cases.

Materials and Methods. The article presents the experience of treatment of 142 patients with liver abscesses. 89 surgeries were performed by laparotomy access, 36 percutaneous drainage by ultrasound navigation, 17 surgical interventions by minimally invasive laparoscopic drainage. The age of patients varied from 26 to 84 years. LAs were 1.41 times more common in women than in men. The duration from the initial manifestation to hospitalization ranged from 4 days to 1 month. Concomitant pathology was in 121 patients (85.2\%).

Results and Discussion. LA were most often located in the following segments of the liver: 3rd segment - (14.54 \pm 2.85$) \%$, 6th segment

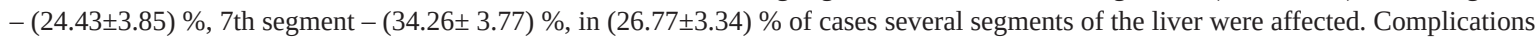
were represented by suppuration of the postoperative wound - $6(6.37 \pm 3.25) \%$, exudative pleuritis on the right 7 (5.16 \pm 2.85$) \%$ bile leakage $-4(3.01 \pm 2.58) \%$, pneumonia $-6(6.04 \pm 2.63) \%$, early adhesive intestinal obstruction -3 (3.03 \pm 2.14$) \%$. The length of hospital stay of patients with minimally invasive treatments for LA was shorter $(5.7 \pm 0.4)$ days comparing with open surgery $(14.7 \pm 1)(p<0.05)$. Preference should be given to minimally invasive treatments that are highly effective, safe, reduce the length of hospital stay and reduce mortality up to $7.04 \%$. If the chosen method is ineffective, surgical tactics should be based on the escalation principle, which is a timely transition to a more effective and invasive method.

Key words: liver abscess (LA); percutaneous echo-controlled minimally invasive interventions; open surgery. 